\title{
A Surfactant, Oxidant and Inhibitor Compatible Thermo-solvent-tolerant Amylase From a Novel Extrimophilic Bacillus Subtilis Strain Clb-34 Mk443366: Study on Purification and Characterization
}

Soni Tiwari ( $\square$ rajeevagaur@gmail.com )

Department of Soil Science and Agricultural chemistry, IAS, Banaras Hindu University, Varanasi-221005, Uttar Pradesh, India.

\section{Rajeeva Gaur}

Department of Microbiology (Centre of Excellence), Dr. Ram Manohar Lohia Avadh University, Faizabad224001, Uttar Pradesh, India

\section{Research}

Keywords: Bacillus subtilis, 16S rDNA, Solvent stability, Heavy metal resistance, Thermotolerant

Posted Date: September 4th, 2020

DOI: https://doi.org/10.21203/rs.3.rs-63514/v1

License: (9) (i) This work is licensed under a Creative Commons Attribution 4.0 International License. Read Full License 


\section{Abstract}

It is the first time when thermo-tolerant, heavy metal resistance amylase producing strain Bacillus subtilis isolated from soil sample. Amylase was purified 3.8-fold with a specific activity of $11,305.0 \mathrm{U} \mathrm{mg}^{-1}$. The molecular weight of purified amylase was $67 \mathrm{kDa}$ as revealed by SDS-PAGE and activity gel analysis. The amylase was active in broad $\mathrm{pH}$ and temperature range of $4.0-11.0$ and $35-110^{\circ} \mathrm{C}$, respectively, with maxima at $\mathrm{pH} 7.0$ and $85^{\circ} \mathrm{C}$ temperature. The amylase has $\mathrm{Km}$ and $\mathrm{Vmax}$ value of $2.181 \mathrm{mg} \mathrm{ml}^{-1}$ and $909.09 \mu \mathrm{g} \mathrm{ml}^{-1} \mathrm{~min}^{-1}$, respectively when starch used as substrate. The amylase was not only stable but also its activity enhanced in the presence of n-dodecane, iso-octane, n-decane, xylene, toluene, n-butanol, acetone, and cyclohexane, after prolonged incubation (7 days). Amylase activity and stability was inhibited in the presence of $\mathrm{Hg}^{2+}$, benzene, sodium perborate. The unique property of solvent tolerance and heavy metal resistance proves the potential candidature of this isolate not only for starch liquefaction for food application but also for bioremediation strategies involved in environmental cleanup.

\section{Introduction}

In modern times, the products of biological origin, particularly enzymes, are attracting the attention of researchers. Their role in several biological and commercial processes has been duly emphasized. Among all the enzymes, a-amylases constitute a class of industrial enzyme having approximately $30 \%$ of the world enzyme production (Van der Maarel Marc et al. 2002) and represent one of the three largest groups of industrial enzymes and account for approximately $25 \%$ of total enzymes sales in the world (Rao et al. 1998) and are an important enzyme, particularly in the process of starch or glycogen hydrolysis.

The amylases can be derived from several sources such as plants, animals and microbes. The major advantage of using microorganisms for production of amylases is in economical bulk production capacity and microbes are also easy to manipulate to obtain enzymes of desired characteristics (Aiyer 2005; Vidyalakshmi et al. 2009). Based on their mode of action, they are further classified into three categories a-amylases, $\beta$-amylases and glucoamylases. All amylases are glycoside hydrolyser and act on a-1,4 glycosidic bonds (Maton et al. 1993). Industrially, a-amylase is used particularly in starch liquefaction, brewing, textile, pharmaceuticals, paper, detergents, drugs, toxic wastes removal and oil drilling (Ajayi and Fagade 2003). Since a-amylases are active over a broad pH (5-9) and temperature $\left(35-105^{\circ} \mathrm{C}\right)$ ranges, they are world wide center of attraction for researchers. Many microorganisms like fungi, yeast, bacteria and actinomycetes produce this enzyme; however, enzyme from fungal and bacterial sources has dominated applications in industrial sectors (Kim et al. 2012). However, bacterial amylases are preferred as they grow rapidly, need less space, can be easily maintained and are accessible for genetic manipulations. The important amylase producing bacteria are species of Bacillus, Pseudomonas, Halomonas, Arthrobacter and Serratia. Among the bacterial sources Bacillus sp., Bacillus subtilis, B. staerothermophilus, B. amyloliquefaciens, B. licheniformis, B. acidocaldarius, Bifidobacterium 
bifidum, Bacillus atrophaeus and B. macerans (Aiyer 2005; Konsoula and Liakopoulou-Kyrikides 2006; Enhasy 2007; Kim et al. 2012; Simair et al. 2107; Abd-Elaziz et al 2020) play an important role in production of amylase. Several species of Bacillus are industrially employed to produce thermostable amylase as they grow easily under extreme $\mathrm{pH}$ and temperature conditions.

The application of an amylase in industrial reactions depends on its unique characteristics, such as its action pattern, substrate specificity, major reaction products, optimal temperature, and optimal pH (Yun et al. 2004). They are mainly employed for starch liquefaction to reduce their viscosity, production of maltose, oligosaccharide mixtures, high fructose syrup and maltotetraose syrup. In detergents production, they are applied to improve cleaning effect and are also used for starch de-sizing in textile industry (Chengyi et al. 1999). Generally production of this enzyme has been carried out by submerged fermentation (Enhasy 2007) because of the ease of sterilization and process control easier to engineer in these systems. The purpose this studies to isolate a novel thermoloterant amylase producing bacteria in the presence of organic solvent. Purification and characterization of amylase by bacteria was also performed in this study.

\section{Materials And Methods 2.1. Materials}

All analytical grade reagents and media components were purchased from Hi-Media (Bombay, India) and Merk (India). Column chromatography materials, protein ladder for electrophroresis, and starch were procured from Sigma-Aldrich Pvt. Ltd., USA.

\subsection{Microorganism}

Bacillus subtilis strain CLB-34 MK443366 used in this study was isolated from the soil sample and identified on the basis of phenotypic (16S r DNA) and biochemical tests. Analysis of 16S rDNA sequence (799 bp) revealed its $95.0 \%$ homology with Bacillus subtilis strains, and was designated as Bacillus subtilis CLB-34. The 16S rDNA sequence of Bacillus subtilis was submitted to Gene bank [MK: 443366] and a link to the dataset is https://www.ncbi.nlm.nih.gov/nuccore/MK443366 (All details are submitted in the form of Supporting Data). The strain CLB-34 was in the same cluster of phylogenetic tree (Fig. 1) with different strains of Bacillus subtilis. It was maintained on starch nutrient agar slants at $4{ }^{\circ} \mathrm{C}$.

\subsection{Crude enzyme preparation}

One full loop of $24 \mathrm{~h}$ grown culture take from nutrient starch slant was transferred in $50 \mathrm{ml}$ basal broth (2.0\%, starch; $0.5 \%$, peptone; $0.3 \%$, beef extract; $0.5 \%, \mathrm{NaCl})$ and incubated at $55{ }^{\circ} \mathrm{C}$ for $24-48$. To obtain crude enzyme, culture broth was transferred to micro-centrifuge tubes and centrifuged at $10000 \mathrm{rpm}$ for $10 \mathrm{~min}$. Cells were discarded and resultant supernatant was used as the crude enzyme for various enzyme assay.

\subsection{Enzyme assay}


The activity of a-amylase was assayed by measuring the reducing sugar released by reaction on starch. Amylase assay was done (Nelson 1944; Somogyi 1952) by using a reaction mixture consisting $500 \mu \mathrm{l}$ of substrate solution ( $1.0 \%$ soluble starch in $1.0 \mathrm{M}$ phosphate buffer $\mathrm{pH} 7.0), 100 \mu$ l of the enzyme solution and $1 \mathrm{ml}$ volume make up by adding $400 \mu \mathrm{l}$ distilled water. The reaction mixture was incubated for $10 \mathrm{~min}$ at $55^{\circ} \mathrm{C}$. Reaction was stopped by adding $1 \mathrm{ml}$ of alkaline copper tartrate solution and incubated in boiling water bath for 10 min and cooled, then added arsenomolybdate solution for color stabilization. Optical density of each sample with reaction mixture was taken at $620 \mathrm{~nm}$ in a spectrophotometer (Shimadzu, Japan). One unit of enzyme activity was defined as the amount of enzyme that liberates $1.0 \mu \mathrm{g}$ of glucose $\mathrm{min} / \mathrm{ml}$.

\subsection{Extraction and Purification of Amylase}

A three step purification method was used to purify the amylase produced by the $B$. subtilis CLB-34. All the purification steps were performed at temperatures between 0 and $4{ }^{\circ} \mathrm{C}$ unless otherwise stated.

\subsubsection{Enzyme extraction}

The crude culture supernatant obtained from $24 \mathrm{~h}$ old cultures of $B$. subtilis CLB-34 grown under optimal conditions was subjected to purification. The crude culture filtrate was subjected to a cooling centrifugation at 10,000 rpm to remove the cells and the residual medium. The resulted supernatant was used as crude enzyme extract.

\subsubsection{Acetone precipitation}

The cell free crude enzyme was saturated by the addition of different volumes ( $45 \%, 55 \%, 65 \%$ and $75 \%$ ) of enzyme grade chilled acetone with gentle stirring on ice-bath. The mixture was left at $4{ }^{\circ} \mathrm{C}$ for $4 \mathrm{~h}$ and the precipitate was recovered by centrifugation at $10,000 \mathrm{~g}$ for $10 \mathrm{~min}$. The supernatant was drained off and precipitate was kept at room temperature for few minutes to remove traces of acetone. The precipitate was dissolved $100 \mathrm{mM}$ phosphate buffer ( $\mathrm{pH}$ 7.0). The corresponding precipitates were recovered, dissolved individually in fresh buffer and assayed for both total protein content and amylase activity.

\subsubsection{Ion exchange chromatography}

An anion-exchanger (Q-sepharose) column (Sigma-Aldrich Pvt. Ltd., USA; $15 \times 70 \mathrm{~mm}^{2}$ ), pre-equilibrated with $100 \mathrm{mM}$ phosphate buffer ( $\mathrm{pH} 7.0$ ) was used for further purification of the enzyme. The active fraction of acetone precipitates was suitably diluted (final volume $3 \mathrm{ml}$ ) with $100 \mathrm{Mm}$ phosphate buffer (pH 7.0) prior to loading on column and the flow rate was adjusted to $20 \mathrm{ml} / \mathrm{h}$. Afterthat, the diluted enzyme fraction was allowed to bind with matrix for $2 \mathrm{~h}$ at $4{ }^{\circ} \mathrm{C}$. Then the unbound fraction was collected and analyzed for enzyme activity and for protein content. After collecting the loaded sample, column was washed with the same buffer until OD620 of the effluent was zero. The bound fractions were eluted with a linear gradient of $\mathrm{NaCl}(0.1-0.5 \mathrm{M}, 10 \mathrm{ml}$ each) in the same buffer. 


\subsubsection{Gel filtration chromatography on Sephadex G-75 column}

The partially purified enzyme was applied to gel-filtration chromatography for purification up to homogeneity. The Sephadex-75 column (Sigma Aldrich Pvt. Ltd., USA, $1.5 \times 40 \mathrm{~cm}$ ) was equilibrated with sodium phosphate buffer $(100 \mathrm{mM}, \mathrm{pH} 7.0)$ and $1 \mathrm{ml}$ of concentrated sample was applied to the column. The flow rate was adjusted to $5-6 \mathrm{ml} / \mathrm{h}$ and fraction of $2 \mathrm{~mL}$ each was collected. Amylase activity and estimation of protein content were determined for each individual fraction.

\subsection{Determination of protein concentrations}

Quantitative estimation of protein content was done by the method of Lowry et al. (1951) using Bovine serum albumin (BSA) as standard and expressed as $\mathrm{mg} / \mathrm{ml}$. The protein content of individual fraction obtained after different steps of chromatography was monitored by measuring the extinction at $280 \mathrm{~nm}$.

\subsection{Polyacrylamide gel electrophoresis}

The active fraction, with maximum specific activity, obtained after gel filtration chromatography along with crude, acetone precipitate and anion-exchange chromatography was electrophorezed by Sodium Dodecyl Sulphate-Poly Acrylamide Gel Electrophoresis in a $12.5 \%$ polyacrylamide gel according to the method of Laemmli (1970). Approximate molecular weight of the amylase was estimated by SDS-PAGE against the molecular mass markers i.e. lysozyme (14.3 kDa), $\beta$-lactoglobulin (20 kDa), Carbonic anhydrase (29 kDa), ovalbumin (43 kDa), bovine serum albumin (66 kDa) and phosphorylase $B$ (97.4 kDa) (Sigma-Aldrich Pvt Ltd., USA) run with the samples.

\subsection{Characterization of Purified Enzyme}

\subsubsection{Effect of temperature on enzyme activity and stability:}

The influence of temperature on activity of amylase was studied by incubating the reaction mixture at different temperatures $\left(35-110^{\circ} \mathrm{C}\right)$. The enzyme was incubated at different temperatures $35-110^{\circ} \mathrm{C}$ for $1 \mathrm{~h}$ to study the stability of the enzyme. The residual amylase activity was measured by conducting the reaction at temperature $55^{\circ} \mathrm{C}$ and $\mathrm{pH} 7.0$. The activity of the enzyme was considered as $100 \%$ under standard assay conditions.

\subsubsection{Effect of pH on enzyme activity and stability:}

The effect of $\mathrm{pH}$ on amylase activity was measured in the $\mathrm{pH}$ range of 4 to 11 , using the appropriate buffers at concentration of $100 \mathrm{mM}$ (4.0-6.0, sodium acetate; $6.0-8.0$, sodium phosphate; $8.0-10.0$, Tris$\mathrm{HCl} ; 9.0-11.0$, glycine- $\mathrm{NaOH}$ ) under standard assay conditions. To study stability as a function of $\mathrm{pH}$, $100 \mu \mathrm{l}$ of the purified enzyme was mixed with $100 \mu \mathrm{l}$ of the buffer solutions and incubated at $55^{\circ} \mathrm{C}$ for $1 \mathrm{~h}$ then aliquots of the mixture were taken to measure the residual amylase activity (\%) under standard assay conditions. 


\subsubsection{Effect of metal ions on activity and stability}

The effect of various metal ions ( $5 \mathrm{mM}$ and $10 \mathrm{mM}$ ) on enzyme activity was investigated using $\mathrm{FeSO}_{4}$, $\mathrm{CaCl}_{2}, \mathrm{KCl}, \mathrm{NaCl}, \mathrm{MgCl}_{2}, \mathrm{MnCl}_{2}, \mathrm{ZnSO}_{4}, \mathrm{CuSO}_{4}, \mathrm{HgCl}_{2}$ and $\mathrm{NiCl}_{2}$. The enzyme was incubated with different metals at $55^{\circ} \mathrm{C}$ for $1 \mathrm{~h}$ to study metal ion stability and assayed under standard assay conditions.

\subsubsection{Effect of organic solvent on amylase stability}

Cell free supernatant having maximum amylase activity was filtered with nitrocellulose membrane (pore size $0.22 \mu \mathrm{m}$ ) and incubated with $30 \%$ (v/v) of different organic solvent viz., n-dodecane, n-decane, isooctane, xylene, $\mathrm{n}$-hexane, n-butanol, cyclohexane, acetone, toluene, benzene, ethanol, methanol and propanol for 1 week in screw crapped tubes at $55^{\circ} \mathrm{C}$ and $120 \mathrm{rpm}$. The residual amylase activity was estimated against the control, in which solvent was not present.

\subsubsection{Effect of inhibitors, surfactants, commercial detergents and oxidizing agents on enzyme stability}

The amylase sample was incubated with inhibitors viz., ethylene diamine tetra acetic acid (EDTA), $\beta$ mercaptoethanol, Phenyl methyl sulphonyl flouride (PMSF) and urea ( $5 \mathrm{mM}$ and $10 \mathrm{mM}$ ), surfactants viz., Triton-X-100, Tween-40, Tween-60, Tween-80, SDS (0.1 and 1.0\%, v/v), commercial detergents viz., surf, aerial, ghari, henko and fena $(0.1$ and $1.0 \%, w / v)$, and oxidizing agents viz., $\mathrm{H}_{2} \mathrm{O}_{2}(0.1$ and $1.0 \%, \mathrm{v} / \mathrm{v})$, sodium perborate and sodium hypochlorite $(0.1,0.5$ and $1.0 \%, v / v)$ for $1 \mathrm{~h}$ at $55^{\circ} \mathrm{C}$ and then the residual activity (\%) was tested under standard assay conditions.

\subsubsection{Substrate specificity}

Substrate specificity of the purified enzyme was determined by assaying with different substrates (Soluble starch, Dextrin, Pullulan, a-cyclodextrin, $\beta$ - cyclodextrin, $\gamma$-cyclodextrin, wheat starch, Potato starch, Rice starch) using $1 \%(\mathrm{w} / \mathrm{v})$ concentration at $\mathrm{pH} 7.0$ and $55^{\circ} \mathrm{C}$. The enzyme activity on soluble starch was defined as $100 \%$, and the enzyme activities on other substrates were calculated as relative activities.

\subsubsection{Kinetic analysis}

The influence of substrate concentration on the reaction velocity of the purified amylase was studied with starch. The purified amylase was incubated with various concentration of starch. The final concentration ranged from $0.25-4.0 \mathrm{mg} / \mathrm{ml}$. In all cases, the enzymatic activity was assayed under standard conditions. The Michaelis constant $\left(\mathrm{K}_{\mathrm{m}}\right)$ and maximum velocity $\left(\mathrm{V}_{\mathrm{max}}\right)$ was determined from Lineweaver-Burk plots of Michaelis-Menten equation.

The linear velocity data was plotted as the function of concentration of the substrate by linear transformation of the Michaelis-Menten equation and usual non-linear curve fitting of the MichaelisMenten equation for the calculation of $\mathrm{K}_{\mathrm{m}}$ and $\mathrm{V}_{\max }$ of the reaction. 


\subsection{Enzymatic reaction product analysis}

The purified enzyme was used at a dose of $0.5 \mathrm{U} / \mathrm{mg}$ soluble starch in $100 \mathrm{mM}$ phosphate buffer $(\mathrm{pH} 7.0)$ at $55^{\circ} \mathrm{C}$ and at different time intervals $(2 \mathrm{~h}, 8 \mathrm{~h}$ and $12 \mathrm{~h}$ ). Hydrolysis products were subjected to analyzed by High-performance liquid chromatography (HPLC) using a Hypersil $\mathrm{NH}_{2}$ column at $50{ }^{\circ} \mathrm{C}$ using a $75 \%$ acetonitrile (V/V) was used as mobile phase at a flow rate of $1.0 \mathrm{ml} / \mathrm{min}$ and the hydrolysis products were detected using a RID-10A SHIMADZU refractive detector. Authentic chromatographic grade glucose, maltose, maltotriose, maltotetrose, and maltopentose were used as standards for identification of the hydrolysis products in the reaction mixture.

\subsection{Statistical analysis}

Each experiment with the required controls was performed in triplicate and the data are presented as the mean \pm one standard deviation (SD). Significance of the differences between means was tested for by analysis of variance (ANOVA) and Duncan's multiple means tests (DMMT) on the parametric or arc-sine square root transformed data using the SPSS software, where a value of less than 0.05 was considered as significant.

\section{Results And Discussion 3.1. Culture identification}

The 16S rRNA gene sequencing has been by far the most common housekeeping genetic marker to study bacterial phylogeny and taxonomy attributed to (i) its presence in almost all bacteria, often existing as a multigene family, or operons; (ii) the function of the 16S rRNA gene over time has not changed, suggesting that random sequence changes are a more accurate measure of time (evolution); and (iii) the 16S rRNA gene (1,500 bp) is large enough for informatics purposes (Patel 2001). In the present investigation, the 16S rDNA sequence analysis revealed its maximum closeness with Bacillus subtilis hence the isolate was designated as Bacillus subtilis CLB-34. However, the 16S rDNA sequence analysis indicates that it is a different and novel strain of Bacillus subtilis (Fig. 1).

\subsection{Purification of extra-cellular a-amylase}

The crude enzyme extract was first concentrated by acetone precipitation. Maximum activity was observed in the fraction obtained by the addition of acetone in $50 \%$ with protein content of $25.67 \mathrm{mg} / \mathrm{ml}$. This fraction had $11,305.0 \mathrm{U} / \mathrm{mg}$ of specific activity with recovery of $79.7 \%$ and with regard to purification it showed 3.8-fold purification (Table 1). 
Table 1

Summary of purification of Amylase from Bacillus subtilis

\begin{tabular}{|llllll|}
\hline $\begin{array}{l}\text { Purification } \\
\text { Steps }\end{array}$ & $\begin{array}{l}\text { Total activity } \\
(\mathbf{U})\end{array}$ & $\begin{array}{l}\text { Total protein } \\
(\mathbf{m g})\end{array}$ & $\begin{array}{l}\text { Specific activity }(\mathrm{U} \\
\mathbf{m g}^{-1} \mathbf{)}\end{array}$ & $\begin{array}{l}\text { Yield } \\
(\%)\end{array}$ & $\begin{array}{l}\text { Purification } \\
\text { fold }\end{array}$ \\
\hline Crude & $3,63,890$ & 123.57 & $2,944.80$ & 100 & 1.0 \\
\hline Acetone & $2,90,199.8$ & 25.67 & $11,305.0$ & 79.7 & 3.8 \\
\hline $\begin{array}{l}\text { Q-Sepharose } \\
\text { Sephadex G- }\end{array}$ & $2,48159.1$ & 8.97 & $27,665.4$ & 68.2 & 9.3 \\
75
\end{tabular}

The active fraction of acetone precipitation method was used for further purification by using ion exchange chromatography. Sample $(1 \mathrm{ml})$ was loaded into the Q-Sepharose column pre-equilibrated with sodium phosphate buffer $(100 \mathrm{mM}, \mathrm{pH} 7.0)$ and allowed to pass through the column. The unbound fraction was collected and analyzed for amylase activity and protein content. There was no amylase activity in the fraction, while $2.1 \mathrm{mg} / \mathrm{ml}$ of protein was estimated. The absence of enzyme in unbound fraction suggested that total amylase was bound to matrix. The bound enzyme was eluted by sodium phosphate buffer $(100 \mathrm{mM}, \mathrm{pH} 7.0)$ having $\mathrm{NaCl}$ with increasing concentration at gradient of $0.1 \mathrm{M}$. Ten per $\mathrm{ml}$ solution of each concentration of $\mathrm{NaCl}$ was used to evade the bound enzyme. The amylase activity was detected in the fraction released by the addition of $0.5 \mathrm{M} \mathrm{NaCl}$ Anion-exchange chromatography of amylase on column resulted in one prominent peak at the 24th fraction (Fig. 2).

The active fraction was applied on Sephadex G-75 column. Figure 3 shows the fractionation pattern of amylase on Sephadex G-75 column. One distinctive protein peak was appeared that overlapped with the amylase activity. The purification process resulted in 33.8-fold purification factor and a final recovery of $27.1 \%$ of the enzyme with specific activity of $99,491.4 \mathrm{U} / \mathrm{mg}$ (Table 1). However, Mesbaha and Wiegelb (2014) reported the amylase was purified by a combination of $80 \%$ ethanol precipitation, ion exchange chromatography with $\mathrm{Q}$ sepharose and Superdex ${ }^{\mathrm{TM}} 75$ gel filtration chromatography. The enzyme was purified 4.5 fold with $15.4 \%$ recovery and a specific activity of 250 units/mg protein

\subsection{Electrophoretic analysis}

The purity of the enzyme was confirmed by the presence of a single band on SDS-PAGE and its molecular weight was approximately $67 \mathrm{kDa}$ (Fig. 4), which was similar to Bacillus subtilis and Bacillus sp. DR90 amylase (67 kDa) (Yandri Suhartati and Hadi 2010; Asoodeh et al 2013) but different from licheniformis Isolate Al20 amylase (53 kDa) (Abdulaal 2018).

\subsection{Characterization of purified enzyme}

\subsubsection{Effect of temperature on enzyme activity and stability}


In this experiment the amylase of $B$. subtilis CLB-34 was absolutely stable in the wide temperature range of $35-95^{\circ} \mathrm{C}$ during $1 \mathrm{~h}$ incubation. The enzyme retained $98 \%$ activity even after treatment at $100{ }^{\circ} \mathrm{C}$ (Fig. 5). Similarly $100 \%$ activity at $90^{\circ} \mathrm{C}$ for $1 \mathrm{~h}$ for amylase from Bacillus sp. has been reported by Teodoro and Martins (2000). However, with further increase in every $5{ }^{\circ} \mathrm{C}$ temperature, there was a gradual decrease in enzyme stability ranging between $10-15 \%$ upto $110^{\circ} \mathrm{C}$. The amylase of $B$. subtilis CLB-34 retained 98,88 and $75 \%$ activity even after treatment at 100, 105 and $110^{\circ} \mathrm{C}$, respectively (Fig. 5). The amylase of Bacillus subtilis CLB-34 is more thermostable than amylase studied by several other researchers. Arikan (2007) have reported a thermostable amylase stable up to $60-100{ }^{\circ} \mathrm{C}$ but retained only 96\% activity at $100^{\circ} \mathrm{C}$. Most other thermophile Bacillus amylases reported to so far, amylases exhibited higher temperature optimum for activity and showed good thermal stability (Dong et al. 1997; Horikoshi 1999). These are the properties considered to be very important for industrial starch liquefaction. Hence it is evident that the amylase of Bacillus subtilis CLB-34 is more thermostable, and may be applied to several biotechnological and industrial purposes.

\subsubsection{Effect of pH on enzyme activity and stability}

The $\mathrm{pH}$ stability on the purified amylase of $B$. subtilis CLB-34 was determined by measuring the enzyme activity at varying $\mathrm{pH}$ values ranging from $4.0-11.0$ using different suitable buffers. Figure $5 \mathrm{~b}$ showed that maximum amylase activity was established at $\mathrm{pH} 8.0$, however it was found to be most stable at $\mathrm{pH}$ 7.0 (Fig. 6). The relative activities at pH 4.0, 4.5, 5.0 5.5, 6.0, 6.5, 7.0, 7.5 and 8.0 were determined to be 48, $55,67,80,95,100,115,109$ and $105 \%$, respectively. At pH above 8.0, the amylase activity decreased rapidly. The amylase from Bacillus subtilis CLB-34 was stable in a range of $\mathrm{pH} 5.0-10.5$ and at $\mathrm{pH} 11.0$ approximately $65 \%$ of its activity was retained (Fig. 6). Amylases are generally stable over a wide range of pH from 4.0 to 11.0 (Fogarty and Kelly 1979). For most Bacillus sp. strains, the pH optima and stability of amylase has been reported to be the range of pH 6.0 to 7.0 (Rajagopalan and Krishnan 2008; Mukherjee et al. 2009; Singh and Kumari 2016; Gbenga et al 2017).

\subsubsection{Effect of metal ions on activity and stability}

Results suggest that a-amylase of $B$. subtilis CLB-34 showed maximum relative activity (194\%) and stability $(160 \%)$ in the presence of Calcium ion $(10 \mathrm{mM})$. B. subtilis CLB-34 a-amylases was activated by $10 \mathrm{mM} \mathrm{Ca}^{2+}$ but inhibited by all other metal ions to a variable extent. Abd-Elaziz et al. (2020) also found that thermostability of a-amylase from a Bacillus atrophaeus NRC1 isolated from honey was enhanced in the presence of $10 \mathrm{mM}$ calcium. a-Amylases contain at least one $\mathrm{Ca}^{2+}$ ion and affinity of $\mathrm{Ca}^{2+}$ is much stronger than that of other ions (Abdulaal 2018) slight activity inhibition was observed by $\mathrm{Ni}^{2+}, \mathrm{Mn}^{2+}$, and $\mathrm{Zn}^{2+}$ (Table 2). A stronger inhibitory effect was observed in case of $\mathrm{Cu}^{2+}$ and $\mathrm{Hg}^{2+}$. The same inhibitory effect by $\mathrm{Hg}^{+2}$ and $\mathrm{Cu}^{2+}$ had been reported also by Bacillus cereus (Annamalai et al. 2011), Bacillus licheniformis Isolate Al20 (Abdel-Fattah et al. 2012), Bacillus atrophaeus NRC1 (Abd-Elaziz et al. 2020). The inhibition by $\mathrm{Hg}^{2+}$ may indicate the importance of indole amino acid residues in enzyme function as has been demonstrated for other microbial a-amylases (Gupta et al. 2003). The inhibition of a-amylase 
by $\mathrm{Co}^{2+}, \mathrm{Cu}^{2+}$, and $\mathrm{Ba}^{2+}$ ions could be due to competition between the exogenous cations and the proteinassociated cations, resulting in decreased metalloenzyme activity (Leveque et al. 2000).

Table 2

Effect of metal ions on enzyme activity and stability

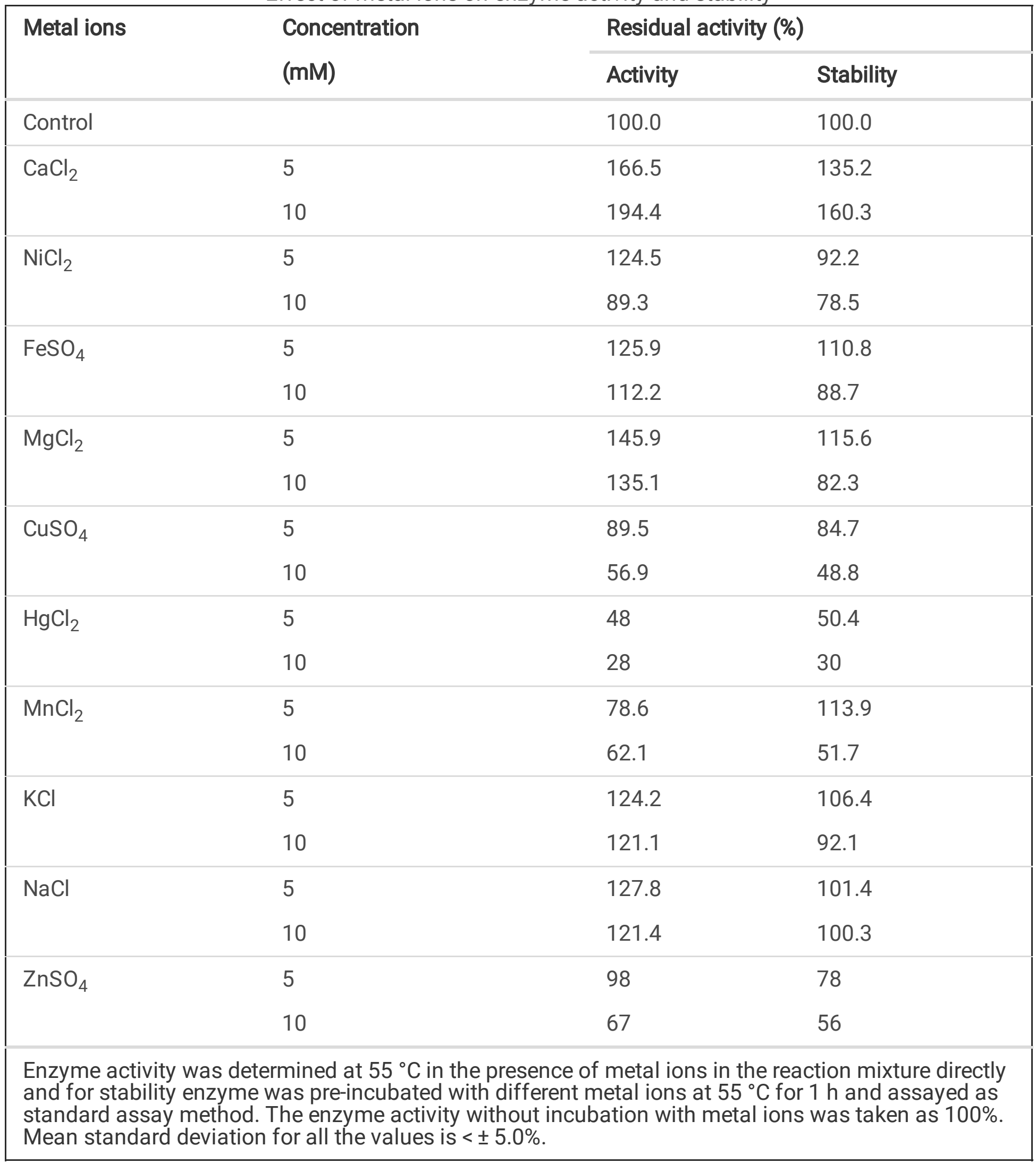




\subsubsection{Effect of organic solvents on amylase stability}

In another experiment, the effect of various organic solvents $(30 \%, \mathrm{v} / \mathrm{v})$ on amylase stability was also investigated for one week, and the results are depicted in Table 3. The amylase of Bacillus subtilis is extraordinarily stable in the presence of all organic solvents under study. It was observed that except benzene, propanol and ethanol, presence of other solvents (n-dodecane, iso-octane, n-decane, xylene, toluene, n-haxane, n-butanol, acetone, methanol and cyclohexane) enhanced the amylase activity (Table 3). After incubation with n-dodecane, iso-octane, n-decane, xylene, Toluene, n-haxane, n-butanol, Acetone, Methanol, and cyclohexane the amylase activity increased to 252.3, 180.1, 188.8, 123, 190.2, $164.3,115.2,137.2$ and $130 \%$, respectively. The presence of benzene, ethanol and propanol marginally reduced the amylase with residual activities of $77,88.3$ and $85.4 \%$, respectively (Table 3). Mesbaha and Wiegel (2014) also reported that amylase of Amphibacillus sp. NM-Ra2 showed enhanced activity in the presence of organic solvents $(25 \%, v / v)$ of log P value reduced the protease activity by $23-38 \%$. It is therefore; evident from our study that amylase of Bacillus subtilis is remarkably stable in the presence of broad range hydrophilic as well as hydrophobic organic solvents employed in this study. 
Table 3

Stability of crude Amylase in presence of various organic solvents

\begin{tabular}{|c|c|c|c|c|c|c|c|c|c|}
\hline \multirow{2}{*}{$\begin{array}{l}\text { Organic solvents } \\
(30 \%)\end{array}$} & \multirow{2}{*}{$\stackrel{\log }{P}$} & \multicolumn{8}{|c|}{ Residual activity (\%) } \\
\hline & & $1 \mathrm{~h}$ & $24 \mathrm{~h}$ & $48 \mathrm{~h}$ & $72 \mathrm{~h}$ & $96 \mathrm{~h}$ & $120 \mathrm{~h}$ & $144 \mathrm{~h}$ & $168 \mathrm{~h}$ \\
\hline Butanol & -0.80 & 122.7 & 164.3 & 148.2 & 135.4 & 127.6 & 120.3 & 115 & 105 \\
\hline Methanol & -0.76 & 103.4 & 135.1 & 137.2 & 128.3 & 120.6 & 115.4 & 108.3 & 99.3 \\
\hline Iso-propanol & -0.28 & 91.2 & 102.3 & 99.3 & 93.4 & 92.5 & 91.4 & 87.3 & 85.4 \\
\hline Ethanol & -0.24 & 99.1 & 108.6 & 107.5 & 102.6 & 99.5 & 95.4 & 91.2 & 88.3 \\
\hline Acetone & -0.23 & 105.1 & 115.2 & 109.6 & 103.1 & 100 & 98.2 & 95.3 & 90.4 \\
\hline Benzene & 2.13 & 100 & 120 & 99.2 & 95.1 & 90.3 & 87.2 & 81.3 & 77.1 \\
\hline Toluene & 2.5 & 121.9 & 190.2 & 160.1 & 138.1 & 130.8 & 122.4 & 115.6 & 109.3 \\
\hline Iso-octane & 2.9 & 130 & 180.1 & 145.5 & 140.5 & 133.4 & 130.3 & 125.7 & 110.2 \\
\hline Xylene & 3.1 & 91.4 & 117.1 & 123.4 & 117.4 & 110.2 & 104.1 & 99.5 & 94.6 \\
\hline Cyclohexane & 3.3 & 90.6 & 112.5 & 130.4 & 109.2 & 100.2 & 99.5 & 90.2 & 87.4 \\
\hline Hexane & 3.6 & 133.8 & 152.7 & 143.5 & 137.5 & 122.3 & 123.6 & 113.7 & 103.8 \\
\hline n-decane & 5.6 & 145.3 & 171.3 & 188.8 & 168.3 & 146.2 & 121.7 & 110.1 & 99.0 \\
\hline n-dodecane & 6.0 & 151.8 & 180.2 & 252.3 & 178.1 & 169.9 & 140.2 & 118.0 & 100.0 \\
\hline
\end{tabular}

\subsubsection{Effect of inhibitors on enzyme stability}

When the Bacillus subtilis amylase enzyme was incubated with EDTA, PMSF, Urea and $\beta$ mercaptoethanol, the enzyme activity was retained at $96.3 \%, 94 \%, 99.4 \%$, and $95.6 \%$ of the original activity at $10 \mathrm{mM}$ (Table 4). Similarly, Kim et al. (2012) reported that Bacillus sp. AAH-31 retained approximately $85 \%$ activity in the presence of $0.1 \%$ (w/v) EDTA, while Abd-Elaziz et al. (2020) reported $28 \%$ activity with $5 \mathrm{mM}$. EDTA generally shows non-competitive inhibition of amylase activity and a slight inhibition showed us it is a metallo-enzyme. Bacillus subtilis CLB-34 a-amylase has also slight inhibition by $3.3 \%$ with $10 \mathrm{mM}$ EDTA. It was reported that amylases from alkaliphilic Bacillus strains were not inhibited by $10 \mathrm{mM}$ EDTA at $40^{\circ} \mathrm{C}$ but was completely inactivated by $8 \mathrm{M}$ urea (Horikoshi 1999). These results show that the Bacillus subtilis a-amylase is an alkaliphilic enzyme. Bacillus subtilis CLB-34 aamylase has also slight inhibition by $6 \%$ with $10 \mathrm{mM}$ PMSF. Similarly Lin et al. (1998) were also reported similar result (97\% with $10 \mathrm{mM}$ ) while Abd-Elaziz et al. (2020) reported that Bacillus sp. showed $81.3 \%$ activity with $5 \mathrm{Mm}$ PMSF. Bacillus subtilis CLB-34 amylase has also slight inhibition by $4.4 \%$ with $1.0 \% \beta$ mercaptoethanol. Similarly Ozcan et al. (2010) reported that 1.0\% $\beta$-mercaptoethanol inhibit only $5 \%$ 
residual activity by alkanophilic Bacillus sp. DM-15. On contrary to our result, Anupama and Jayaraman (2011) reported only $48 \%$ relative enzyme activity at $2 \mathrm{mM}$ with $\beta$-mercaptoethanol. 
Table 4

Effect of different inhibitors, surfactants, commercial detergents and oxidizing agents on amylase stability

\begin{tabular}{|c|c|c|}
\hline Surfactants & Concentration (\%) & Residual activity (\%) \\
\hline Control & & 100.0 \\
\hline \multirow[t]{2}{*}{$\beta$-mercaptoethanol } & $0.1(\%)$ & 109.6 \\
\hline & $1.0(\%)$ & 95.6 \\
\hline \multirow[t]{2}{*}{ EDTA } & $5 \mathrm{mM}$ & 120 \\
\hline & $10 \mathrm{mM}$ & 96.7 \\
\hline \multirow[t]{2}{*}{ Urea } & $5 \mathrm{mM}$ & 119 \\
\hline & $10 \mathrm{mM}$ & 99.4 \\
\hline \multirow[t]{2}{*}{ PMSF } & $5 \mathrm{mM}$ & 105.4 \\
\hline & $10 \mathrm{mM}$ & 94 \\
\hline \multirow[t]{2}{*}{ Tween-40 } & 0.1 & 110.0 \\
\hline & 1.0 & 99.6 \\
\hline \multirow[t]{2}{*}{ Tween-60 } & 0.1 & 115.7 \\
\hline & 1.0 & 99.7 \\
\hline \multirow[t]{2}{*}{ Tween-80 } & 0.1 & 106.4 \\
\hline & 1.0 & 96.5 \\
\hline \multirow[t]{2}{*}{ Triton-X-100 } & 0.1 & 109 \\
\hline & 1.0 & 97 \\
\hline \multirow[t]{2}{*}{ SDS } & 0.1 & 120 \\
\hline & 1.0 & 95 \\
\hline \multirow[t]{2}{*}{ Ghari } & 0.1 & 97.1 \\
\hline & 1.0 & 75.2 \\
\hline \multirow[t]{2}{*}{ Ariel } & 0.1 & 94.7 \\
\hline & 1.0 & 61.3 \\
\hline
\end{tabular}

Enzyme was pre-incubated with different inhibitors, surfactants, commercial detergents and oxidizing agents at $55^{\circ} \mathrm{C}$ for $1 \mathrm{~h}$ and assayed as standard assay method. The enzyme activity without incubation with inhibitor, surfactants, commercial detergents and oxidizing agents was taken as $100 \%$. Mean standard deviation for all the values is $< \pm 5.0 \%$. 


\begin{tabular}{|c|c|c|}
\hline Surfactants & Concentration (\%) & Residual activity (\%) \\
\hline \multirow[t]{2}{*}{ Surf Excel } & 0.1 & 91.6 \\
\hline & 1.0 & 55.6 \\
\hline \multirow[t]{2}{*}{ Fena } & 0.1 & 99.4 \\
\hline & 1.0 & 78.4 \\
\hline \multirow[t]{2}{*}{ Henko } & 0.1 & 99.2 \\
\hline & 1.0 & 65.9 \\
\hline \multirow[t]{3}{*}{ Sodium perborate } & $0.1(\%)$ & 85.8 \\
\hline & $0.5(\%)$ & 66.8 \\
\hline & $1.0(\%)$ & 55.3 \\
\hline \multirow[t]{3}{*}{ Sodium hypochlorite } & $0.1(\%)$ & 121.9 \\
\hline & $0.5(\%) 1.0(\%)$ & 113.2 \\
\hline & & 98.4 \\
\hline \multirow[t]{2}{*}{$\mathrm{H}_{2} \mathrm{O}_{2}$} & $0.1(\%)$ & 114.5 \\
\hline & $1.0(\%)$ & 89.2 \\
\hline \multicolumn{3}{|c|}{$\begin{array}{l}\text { Enzyme was pre-incubated with different inhibitors, surfactants, commercial detergents and oxidizin } \\
\text { agents at } 55^{\circ} \mathrm{C} \text { for } 1 \mathrm{~h} \text { and assayed as standard assay method. The enzyme activity without } \\
\text { incubation with inhibitor, surfactants, commercial detergents and oxidizing agents was taken as } \\
100 \% \text {. Mean standard deviation for all the values is }< \pm 5.0 \% \text {. }\end{array}$} \\
\hline
\end{tabular}

\subsubsection{Effect of surfactant on enzyme stability}

In order to have applications in detergent industries, amylase must be stable to various detergent ingredients, such as surfactants. As shown in Table 4 the enzyme was appreciably stable in the presence of non-ionic surfactants like Tween-40, Tween-60 Tween-80 and Tritone-100 and detergent SDS. However, these compounds slightly inhibited the amylase activity with $99.6,99.7,96.5,97.0,95.0 \%$ of residual activity at concentration $1.0 \%$ (v/v). Similarly, Kim et al. (2012) reported that, a highly thermostable and alkaline amylase was fully stable in $1 \%(\mathrm{w} / \mathrm{v})$ of Tween 20 , Tween 80 , and Triton $\mathrm{X}-100$, and $0.1 \%(\mathrm{w} / \mathrm{v})$ of SDS. Our results was indicated that, Bacillus subtilis CLB-34 amylase enzyme highly stable with $1 \%$ SDS (95\%). Abd-Elaziz et al. (2020) also stated that Bacillus atrophaeus NRC1 was resistant $87.5 \%$ to $5 \mathrm{mM}$ SDS, additionally Lo et al. (2001) reported that SDS had no marked effect on enzyme activity ion as concentration $8 \%$. This resistance, which is essential requirements, suggests that the enzyme may be used as an effective additive in detergents.

\subsubsection{Effect of detergent agents on enzyme stability}


The amylase was substantially stable with commercial detergents at lower concentration $(0.1 \%, \mathrm{w} / \mathrm{v})$. RG09 showed $99.4,99.2,97.1,94.7$ and $91.6 \%$ of residual at concentration $0.1 \%(\mathrm{w} / \mathrm{v})$ with fena, henko, ghari, ariel, surfexcel. However, these compounds inhibited the amylase activity at higher concentration $(1.0 \%, w / v)$ (Table 4). Simair et al. (2017) also reported $69.73-79.33 \%$ residual activity with amylase from Bacillus sp. BCC 01-50 in the presence of commercial detergents. In another study, Bancerz and Ginalska (2007) reported that lipase from Bjerkandera adusta R59 showed sufficient compatibility with commercial detergents.

\subsubsection{Effect of oxidizing agents on enzyme stability}

Among the oxidizing agents tested the amylase activity enhanced in presence of sodium hypochlorite and $\mathrm{H}_{2} \mathrm{O}_{2}$ with residual activities 121.9 and $114.5 \%$ at concentration $0.1 \%$, whereas, higher concentrations $(0.5$ and $1.0 \%)$ decreased the stability except sodium hypochlorite $(113.2 \%$ residual activity at concentration $0.5 \%$, w/v) (Table 4). Likewise, Wang et al. (2009) also reported that lipase from B. cepacia was highly stable in the presence of hydrogen peroxide, sodium hypochlorite and sodium perborate after $1 \mathrm{~h}$. Mesbaha and Wiegelb (2014) also reported that $\mathrm{H}_{2} \mathrm{O}_{2}$ enhance the enzyme activity at the concentration of $1 \%$. The stability profile of the amylase in the presence of detergents and oxidizing agents prove its potential application in the detergent formulations as these agents are the active components of house hold detergents (Hajji et al. 2007).

\subsubsection{Substrate specificity}

The ability to hydrolyze several carbohydrates is a criterion of amylase potency (Grebeshova et al. 1999), however, the affinity towards a carbohydrates (substrate) may vary with substrate to substrate and for a particular substrate with the source of enzyme. Substrate specificity is defined how different substrates compete for an enzyme and determined by value of kcat/Km (Perona and Craik 1995; Hedstrom 2002). To determine the affinity of the amylase towards different substrates, nine substrates have been used in the reaction mixture (Table 5). The purified enzyme was able to efficiently hydrolyze starch and dextrin with 100 and $82.3 \%$ relative activity. Similarly, Abd-Elaziz et al. (2020) also reported that purified amylase of Bacillus atrophaeus NRC1 showed $100 \%$ starch hydrolysis for substrate specificity experiment. Among cyclodextrins, purified enzyme could easily hydrolyze $\gamma$-cylodextrin but could not hydrolyze $a$ and $\beta$ cyclodextrin. This might be due to the cyclical shape of cyclodextrin contributing to the configuration of substrate and making the substrate low accessibility to the active site of the enzyme, thus making enzyme catalysis difficult. The cyclical shape of cyclodextrin with longer chain showed weaker effect on the configuration of the molecule than other cyclodextrin with shorter chain (Xian et al. 2015). These results are consistent with the similar observation reported earlier (Hashim et al. 2005; Hassan et al. 2011; Xian et al. 2015). Purified enzyme showed very low activity toward pulullan with $15.6 \%$ relative activity (Table 4), maybe as enzyme favors a-1,4 glycosidic bond to a-1,6 glycosidic bond, and the plenty of a-1,6D-glycosidic bonds contribute to the configuration of the substrate and makes enzyme catalysis difficult (Steyn and Pretorius 1995). Most other a-amylases showed lesser activity toward pullulan (Moreira et al. 2004), except for McAA (Han et al. 2013), which reported maximum activity for pullulan. Purified amylase 
showed maximum relative activity for soluble starches from potato, wheat and rice was the substrate. Similarly, Xain et al., (2015) also reported similar finding by Talaromyces pinophilus 1-95.

Table 5

Substrate specificity of amylase

\begin{tabular}{|ll|}
\hline Substrate (1\%) & Relative activity (\%) \\
\hline Soluble starch & 100 \\
\hline Dextrin & 82.3 \\
\hline Pullulan & 15.6 \\
\hline a-cyclodextrin & ND \\
\hline$\beta$ - cyclodextrin & ND \\
\hline -cyclodextrin & 67.9 \\
\hline Potato starch & 98.2 \\
\hline Wheat starch & 96.2 \\
\hline Rice strach & 95.1 \\
\hline $\begin{array}{l}\text { ND }=\text { Not detectable. Substrate specificity was checked by assaying enzyme with } 1 \% \text { (w/v) of } \\
\text { substrates in } 100 \text { mM Phosphate buffer (pH 7.0) at } 55^{\circ} \mathrm{C} \text {. Mean standard deviation for all the values } \\
\text { is < } \pm 5.0 \% \text {. }\end{array}$ \\
\hline
\end{tabular}

\subsubsection{Kinetic analysis}

Kinetic analysis with starch revealed the $\mathrm{K}_{\mathrm{m}}$ and $\mathrm{V}_{\max }$ to be $2.181 \mathrm{mg} / \mathrm{ml}$ and $909.09 \mu \mathrm{g} \mathrm{ml} / \mathrm{min}$, respectively by Linweaver-Burk plot (Fig. 7). Similarly, Amid and Manap (2014) \& Abd-Elaziz et al (2020) reported that purified amylase enzyme showed $\mathrm{Km}$ and Vmax value $2.7 \mathrm{mg} / \mathrm{ml}$ and $34.30 \mathrm{u} / \mathrm{min} / \mathrm{mg}$ \& $1.63 \mathrm{mg} / \mathrm{ml}$ and $526 \mu \mathrm{M} / \mathrm{ml}$.

\subsection{HPLC analysis of hydrolysis products of a-amylase}

The end products of starch hydrolysis by the amylase of Bacillus subtilis CLB-34 were analyzed by HPLC. At an early stage $(2 \mathrm{~h})$, the hydrolysis products were maltose, maltotriose and maltotetraose, maltopentose and with a trace amount of glucose. As the incubation time prolonged, the amount of glucose, maltose and maltotriose increased, but the amount of maltotetraose and maltopentose decreased. After 8 hours of incubation, the amount of maltotetraose was hard to be detected, which was hydrolyzed to smaller one by the amylase of Bacillus subtilis CLB-34. The main products were glucose, maltose and maltotriose, the contents of the three were about $16.45 \%, 58.99 \%$ and $27.41 \%$, respectively, at the time of 14 hours of incubation. However, during the whole process of cultivation, the soluble starch could not be completely hydrolyzed to the three main products by the a-amylase of Bacillus subtilis CLB34 , at the time of 14 hours of incubation, the degree of hydrolysis was about $85.67 \%$. 


\section{Conclusion}

It is the first instance when a thermo-tolerant amylase being reported from a thermo-tolerant solvent tolerant Bacillus subtilis isolate. The strain is unique with respect to several solvents tolerance, heavy metals, surfactant and inhibitor resistance, makes the isolate applicable under stressed conditions. Outstanding solvent stability of the amylase proves its possible application under anhydrous conditions and amylase liquefaction. The amylase activity in broad $\mathrm{pH}$ and temperature range of 4.0-11.0 and 35$110{ }^{\circ} \mathrm{C}$ clearly indicate the thermo-alkaline nature of this enzyme. This enzyme, which possesses unique properties, could be widely used in different types of industries, especially in food and biotechnological applications.

\section{Declarations}

\section{Ethics approval and consent to participate}

This article does not contain any studies with human participants or animals performed by any of the authors.

\section{Consent for publication}

All authors consent to publish this manuscript.

\section{Availability of data and materials}

Name of the repository is NCBI (National Center for Biotechnology Information) where our data's were deposited and a link to the dataset DOI are https://www.ncbi.nIm.nih.gov/nucleotide/MK443365.1 and https://www.ncbi.nlm.nih.gov/nuccore/MN370035.1.

\section{Competing interests}

The author(s) declare that they have no competing interests.

\section{Funding}

This work was supported by the University Grant Commission Delhi, India [F-4-2/2006(BSR)/BL/1718/0049]. The funding bodies played no role in the design of the study or in collection, analysis, or interpretation of data, or in writing the manuscript.

\section{Authors' contributions}

1. S. T. carried out the research work and drafted the manuscript.

2. R. G. has designed the experiment, contributed substantially to analysis and interpretation of data and have given final approval of the version to be published. 
All authors read and approved the final manuscript.

\section{Acknowledgement}

Dr. D.S. Kothari PDF Fellow is greatly acknowledged by all Authors.

\section{Supplementary information}

The supporting data also include in this manuscript as a supporting file.

\section{Authors Detail}

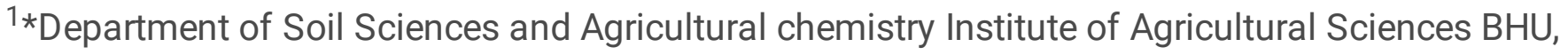
Varanasi-221005, ${ }^{2}$ Department of Microbiology (Centre of Excellence), Dr. Ram Manohar Lohia Avadh University, Faizabad- 224001, Uttar Pradesh, India,

\section{References}

1. Abd-Elaziz AM, Karam EA, Ghanem MM, Moharam ME, Kansoh AL (2020) Production of a novel aamylase by Bacillus atrophaeus NRC1 isolated from honey: Purification and characterization. Inter J Biol Macromole 148:292-301

2. Abdel-Fattah YR, Soliman NA, El-Toukhy NM, El-Gendi H, Ahmed RS (2012) Production, Purification, and Characterization of Thermostable a-Amylase Produced by Bacillus licheniformis Isolate Al20. J Chem 2013:11

3. Abdulaal WH (2018) Purification and characterization of aamylase from Trichoderma pseudokoningii. BMC Biochem 19:4

4. Abusham RA, Rahman RNZRA, Salleh AB, Basri M (2009) Optimization of physical factors affecting the production of thermo-stable organic solvent-tolerant protease from a newly isolated halo tolerant Bacillus subtilis strain Rand. Microb Cell Fact 8:20

5. Aiyer PV (2005) Amylase and their applications. Afr J Biotechnol 4:1525-1529

6. Ajayi AO, Fagade OE (2003) Utilization of corn starch as substrate for $\beta$-amylase by Bacillus spp. Afr J Bio Res 6:37-42

7. Amid M, Manap YA (2014) Purification and characterization of a novel amylase enzyme from red pitaya (Hylocereus polyrhizus) peel. Food Chem 165:412-418

8. Annamalai N, Thavasi R, Vijayalakshmi S, Balasubramanian T (2011) Extraction, Purification and Characterization of Thermostable, Alkaline Tolerant a-Amylase from Bacillus cereus. Indian $\mathrm{J}$ Microbiol 51(4):424-429

9. Anupama A, Jayaraman G (2011) Detergent stable, halotolerant a-amylase from Bacillus aquimaris VITP4 exhibits reversible unfolding. J App Biol Pharm Tech 2:366-376 
10. Arikan B (2007) Highly thermostable, thermophilic, alkaline, SDS and chelator resistant amylase from a thermophilic Bacillus sp. isolate A3-15. Bioresour Technol 99:3071-3076

11. Asoodeh A, Alemi A, Heydari A, Akbari J (2013) Purification and biochemical characterization of an acidophilic amylase from a newly isolated Bacillus sp. DR90. Extremophiles 17:339-348

12. Bancerz R, Ginalska G (2007) A noble thermostable lipase from Basidiomycete Bjerkandera adusta R59: characterization and esterification studies. J Ind Microbiol Biotechnol 34:553-560

13. Chengyi WH, Ming M, Jiang R (1999) Studies on the properties of alpha-amylase produced by Bacillus pumilus 289 (PBX96). Acta Microbial Sin 32:400-404

14. Creig RN, Holt GJ (1984) Bergey's Manual of Systematic Bacteriology. Williams and Willkins, London

15. Dong G, Vieille C, Savchenko A, Zeikus JG (1997) Cloning, sequencing and expression of the gene encoding extracellular alphaamylase from Pyrococcus furiosus and biochemical characterization of the recombinant enzyme. Appl Environ Microbiol 63:3569-3576

16. Egas MCV, da Costa MS, Cowan DA, Pires EMV (1998) Extracellular a-amylase from Thermus filiformis Ork A2: purification and biochemical characterization. Extremophiles 2:23-32

17. Enhasy HAE (2007) Bioprocess development for the production of a-amylase by Bacillus amyloliqufaciens in batch and fed-batch cultures. Res J Microbiol 2:560-568

18. Fogarty WM, Kelly CT (1979) Developments in microbial extra cellular enzymes. In: Wiseman A, (Ed.). Topics Enzy Ferment Biotechnol 3:45-108

19. Gbenga A, David S, Femi B, Saanu AB (2017) Purification and Characterization of a-Amylase from Bacillus subtilis Isolated from Cassava Processing Sites. J Bioremediat Biodegrad 8:6

20. Grebeshova RN, Saldeco-Torres LE, Hodalgo MA (1999) Serine protease of Bacillus subtilis. Appl Biochem Microbiol 35:131-134

21. Gupta R, Gigras P, Mohapatra H, Goswami VK, Chauhan B (2003) Microbial a-amylase: a biotechnological perspective. Process Biochem 38:1599-1616

22. Hagihara H, Igarashi $K$, Hayashi $Y$, Endo K, Ikawa K, Ozaki K, Kawai S (2001) Novel a-amylase that is highly resistant to chelating reagents and chemical oxidants from the alkalophilic Bacillus isolate KSM-K38. Appl Env Microbiol 67:1744-1750

23. Hajji M, Kanoun S, Nasri M, Gharsallah N (2007) Purification and characterization of an alkaline serine-protease produced by a new isolated Aspergillus clavatus ES1. Process Biochem 42:791-797

24. Han P, Zhou P, Hu SQ, Yang SQ, Yan QJ, Jiang ZQ (2013) A Novel Multifunctional a-amylase from the thermophilic fungus Malbranchea cinnamomea: Biochemical characterization and three-dimensional structure. Appl Biochem Biotechnol 170:420-435

25. Hashim SO, Delgado OD, Martinez MA, Kaul RH, Mulaa FJ, Mattiason B (2005) Alkaline active maltohexaose-forming a-amylse from Bacillus haludurans LBK 34. Enz Microb Technol 36:139-146

26. Hassan SA, Ali SA, Abbasi A, Kamal M (2011) Purification and biochemical characterization of a $\mathrm{Ca}^{2+}$ independent, thermostable and acidophilic a-amylase from Bacillus sp. RM16. Afr J Biotechnol 10:6082-6089 
27. Hedstrom L (2002) Serine protease mechanism and specificity. Chem Rev 1024:501-4524

28. Horikoshi K (1999) Alkaliphiles: some applications of their products for biotechnology. Microbiol Mole Biol Rev 63:735-750

29. Igarashi K, Hatada Y, Hagihara H, Saeki K, Takaiwa M, Uemura T (1998) Enzymatic properties of a novel liquefying a-amylase from an alkaliphilic Bacillus isolate and entire nucleotide and amino acid sequences. Appl Environ Microbiol 64:3282-3289

30. Kathiresan K, Manivannan S (2006) a-Amylase production by Penicillum fellutanum isolated from mangrove rhizosphere soil. Afr J Biotechnol 5:829-832

31. Kim DH, Morimoto N, Saburi W, Mukai A, Imoto K, Takehana T, Koike S, Mori H, Matsui H (2012) Purification and Characterization of a Liquefying a-Amylase from Alkalophilic Thermophilic Bacillus sp. AAH-31. Biosci Biotechnol Biochem 76(7):1378-1383

32. Konsoula Z, Liakopoulou-Kyrikides M (2006) Thermostable a-amylase production by Bacillus subtilis entrapped in calcium alginate gel capsules. Enz Microbiol Technol 39:690-696

33. Konsula Z, Liakopoulou-Kyriakides M (2004) Hydrolysis of starches by the action of an a-amylase from Bacillus subtilis. Process Biochem 39:1745-1749

34. Laemmli UK (1970) Cleavage of structural proteins during the assembly of the head of bacteriophage T4. Nature 227:680-685

35. Leveque E, Janecek S, Haye B, Belarbi A (2000) Thermophilic archaeal amylolytic enzymes. Enzy Microb Technol 26:3-14

36. Lin LL, Chyau CC, Hsu WH (1998) Production and properties of a raw-starch-degrading amylase from thermophilic and alkaliphilic Bacillus sp. TS-23. Biotechnol Appl Biochem 28:61-68

37. Liu XD, Xu Y (2008) A novel raw starch digesting "a-amylase from a newly isolated Bacillus sp. YX-1: Purification and characterization. Bioresour Technol 99:4315-4320

38. Lo HF, Lin LL, Chen HL, Hsu HH, Chang CT (2001) Enzymatic properties of a SDS-resistant Bacillus sp. TS-23 a-amylase produced by recombinant Escherichia coli. Process Biochem 36:743-750

39. Lowry OH, Rosenbrough MJ, Farr AL, Randell RJ (1951) Protein measurement with folin phenol reagent. The J Biol Chem 193:265-275

40. Maton A, Jean H, Charles W, Susan J, Maryanna Q, David L, Jill D (1993) Human Biology and Health. Englewood Cliffs, New Jersey: Prentice Hall

41. Mesbaha NM, Wiegel J (2014) Halophilic alkali- and thermostable amylase from a novel polyextremophilic Amphibacillus sp. NM-Ra. Inter J Biol Macromole 70:222-229

42. Moreira FG, Lenartovicz V, Rosane Peralta M (2004) A thermostable maltose-tolerant a-amylase from Aspergillus tamarii. J Basic Microb 44:29-35

43. Mukherjee AK, Borah M, Raí SK (2009) To study the influence of different components of fermentable substrates on induction of extracellular a-amylase synthesis by Bacillus subtilis DM-03 in solid state fermentation and exploration of feasibility for inclusion of a-amylase in laundry detergent formulations. Biochem Eng J 43:149-156 
44. Nelson N (1944) A photometric adaptation of the Somogyi method for the determination of glucose. The J Biol Chem 153:375-380

45. Ozcan BD, Baylan M, Ozcan N, Tekdal D (2010) Characterization of thermostable amylase from thermophilic and alkaliphilic Bacillus sp. Isolate DM-15. Res J Biol Sci 5:118-124

46. Patel JB (2001) 16S rRNA gene sequencing for bacterial pathogen identification in the clinical laboratory. Mol Diagn 6:313-321

47. Perona JJ, Craik CS (1995) Structural basis of substrate specificity in the serine proteases. Protein Sci 4:337-360

48. Rajagopalan G, Krishnan C (2008) Alpha-amylase production from catabolite derepressed Bacillus subtilis KCC103 utilizing sugarcane bagasse hydrolysate. Bioresour Technol 99:3044-3050

49. Rao MB, Tanksale AM, Gathe MS, Deshpande VV (1998) Molecular and biotechnological aspects of microbial proteases. Microbiol Mole Biol Reviews 62:597-635

50. Rathi P, Saxena RK, Gupta R (2001) A novel alkaline lipase from Burkholderia cepacia for detergent formulation. Process Biochem 37:187-192

51. Saxena KR, Dutt K, Agarwal L, Nayyar P (2007) A highly and thermostable alkaline amylase from a Bacillus sp. PN5. Bioresour Technol 98:260-265

52. Shafiei M, Ziaee AA, Amoozegar MA (2011) Purification and characterization of an organic-solventtolerant halophilic a-amylase from the moderately halophilic Nesterenkonia sp. strain F. J Ind Microbiol Biotechnol 38:275-281

53. Simair AA, Qureshi AS, Khushk I, Ali CH, Lashari S, Bhutto MA, Mangrio GS, Lu C (2017) Production and Partial Characterization of $\partial \mathbb{Q}_{\mathrm{1}} 1 / 4-$ Amylase Enzyme from Bacillus sp. BCC 01-50 and Potential Applications. BioMed Res Inter 2017:9

54. Singh P, Kumari P (2016) Isolation and characterization of amylase producing Bacillus spp. from selected soil sample. Int J Res Biosci 5(2):24-29

55. Somogyi M (1952) Notes on sugar determination. The J Biol Chem 195:19-23

56. Steyn AJC, Pretorius IS (1995) Characterization of a novel a-amylase from Lipomyces kononenkoae and expression of its gene (LKA1) in Saccharomyces cerevisiae. Curr Genet 28:526-533

57. Teodoro CED, Martins MLL (2000) Culture conditions for the production of thermostable amylase by Bacillus sp. Brazi J Microbiol 31:298-302

58. Van der Maarel Marc JEC, Van der Veen B, Uitdehaag Joost CM, Hans L, Dijkhuizen L (2002) Properties and applications of starch-converting enzymes of the a-amylase family. J Biotechnol 94:137-155

59. Vidyalakshmi R, Paranthaman R, Indhumathi J (2009) Amylase Production on Submerged Fermentation by Bacillus spp. World J Chem 4:89-91

60. Wang X, Yu X, Xu Y (2009) Homologous expression, purification and characterization of a novel highalkaline and thermal stable lipase from Burkholderia cepacia ATCC 25416. Enz Microb Technol 45:94-102 
61. Xian L, Wang F, Luo X, Feng Y-L, Feng J-X (2015) Purification and Characterization of a Highly Efficient Calcium-Independent a-Amylase from Talaromyces pinophilus 1-95. PLOS ONE 1-18

62. Yandri Suhartati T, Hadi S (2010) Purification and Characterization of Extracellular a-Amilase Enzyme from Locale Bacteria Isolate Bacillus subtilis ITBCCB148. Eur J Sci Res 39:64-74

63. Yun J, Kang S, Park S, Yoon H, Kim MJ, Heu S, Ryu S (2004) Characterization of a novel amylolytic enzyme encoded by a gene from a soil a soil derived metagenomic library. Appl Microbiol Biotechnol $70: 7229-7235$

\section{Figures}

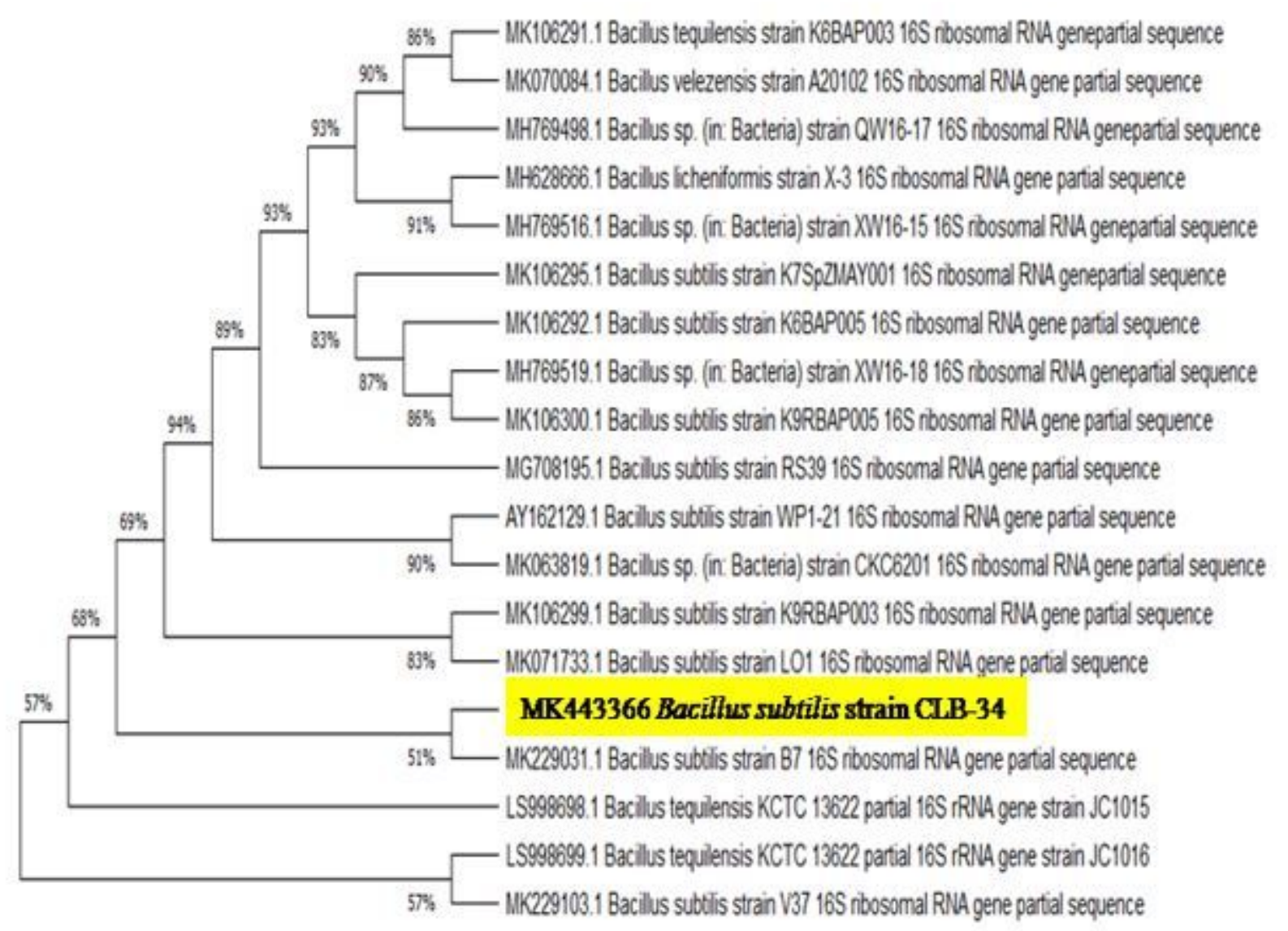

\section{Figure 1}

Phylogenetic tree showing relation between Strain CLB-34 and other Bacillus strains. In phylogenetic tree analysis, the strain was in the same cluster with different strains of Bacillus and showed only $95 \%$ homology to other Bacillus subtilis., so it could be stated that therefore it is different from reported Bacillus subtilis. The phylogenetic tree was drawn by MEGA 6 software using Neighbour-joining method and the significance of junctions was established using bootstrap method (1000 replicates). 


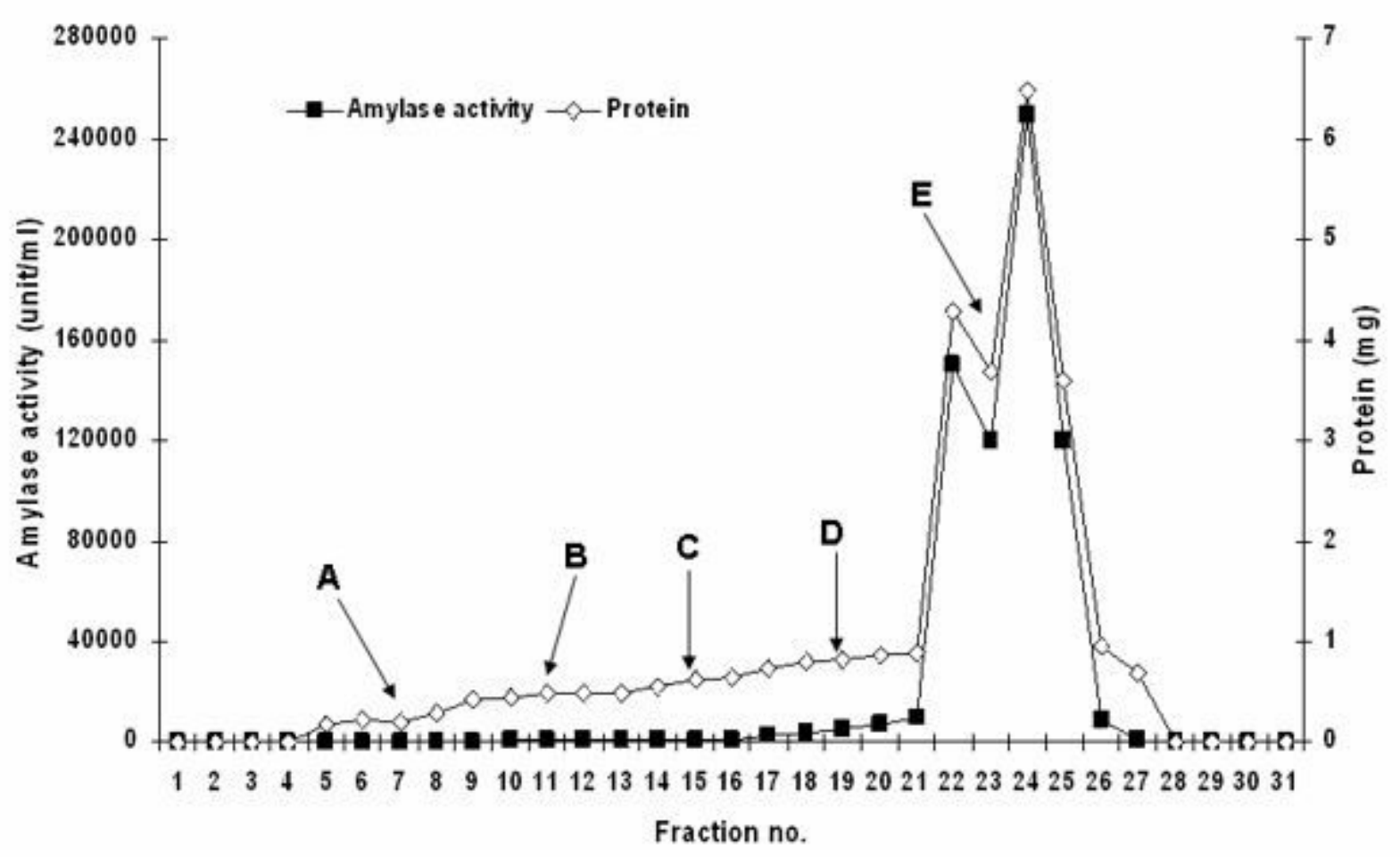

Figure 2

Chromatographic purification profile of extracellular amylase from Bacillus subtilis on anion-exchange column (Q-Sepharose) equilibrated with sodium phosphate buffer ( $100 \mathrm{mM}, \mathrm{pH}$ 7.0). The amylase was eluted with a gradient of sodium chloride $(0.1 \mathrm{M}-0.5 \mathrm{M})$ in sodium phosphate buffer $(100 \mathrm{mM}, \mathrm{pH} 7.0)$. A$0.1 \mathrm{M}, \mathrm{B}-0.2 \mathrm{M}, \mathrm{C}-0.3 \mathrm{M}, \mathrm{D}-0.4 \mathrm{M}, \mathrm{E}-0.5 \mathrm{M}$. 


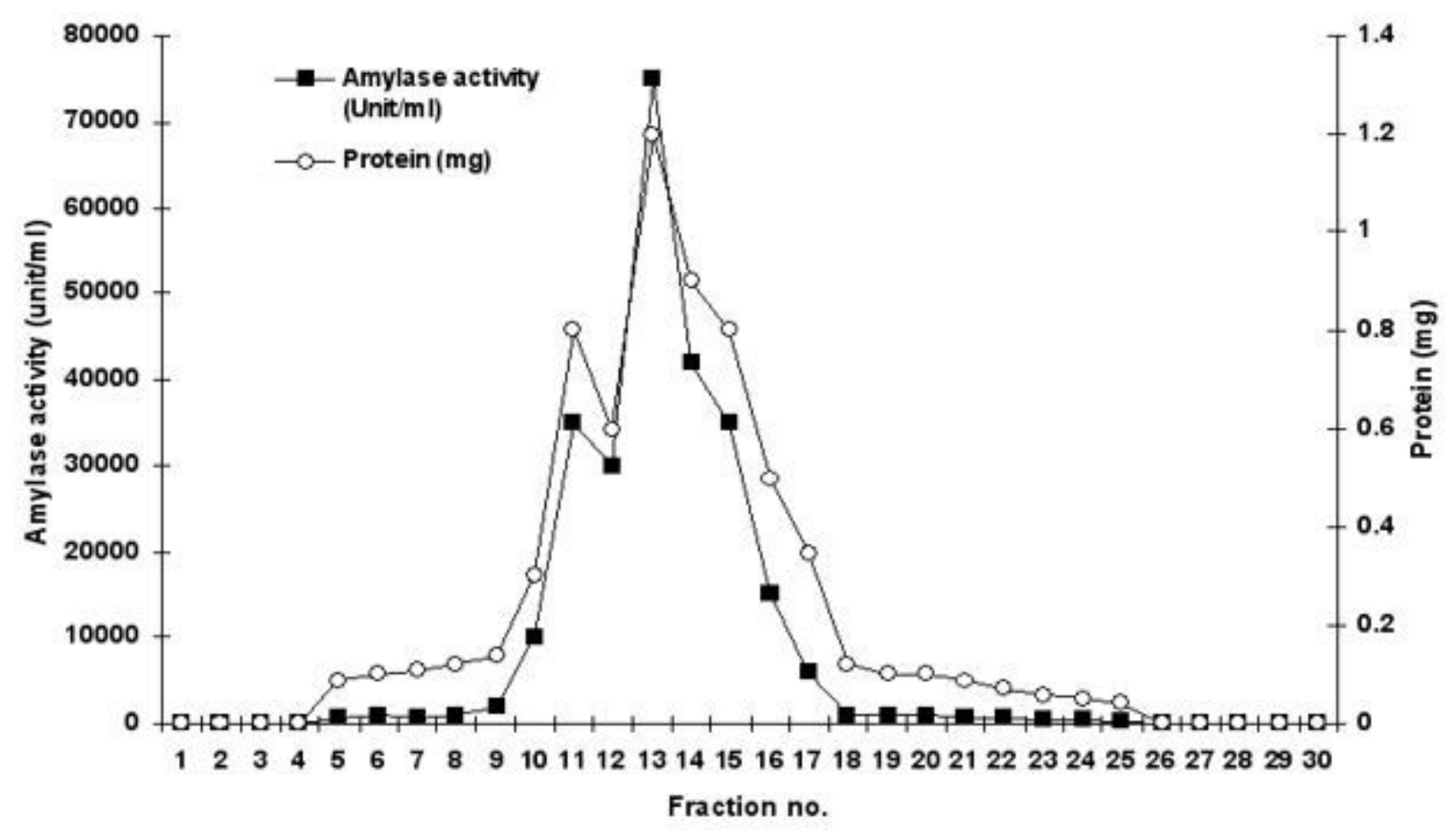

\section{Figure 3}

Chromatographic purification profile of extracellular amylase on Sephadex G-75 gel filtration chromatography. Column was equilibrated with sodium phosphate buffer (100 mM, pH 7.0). The sample was loaded and eluted with the same buffer. 


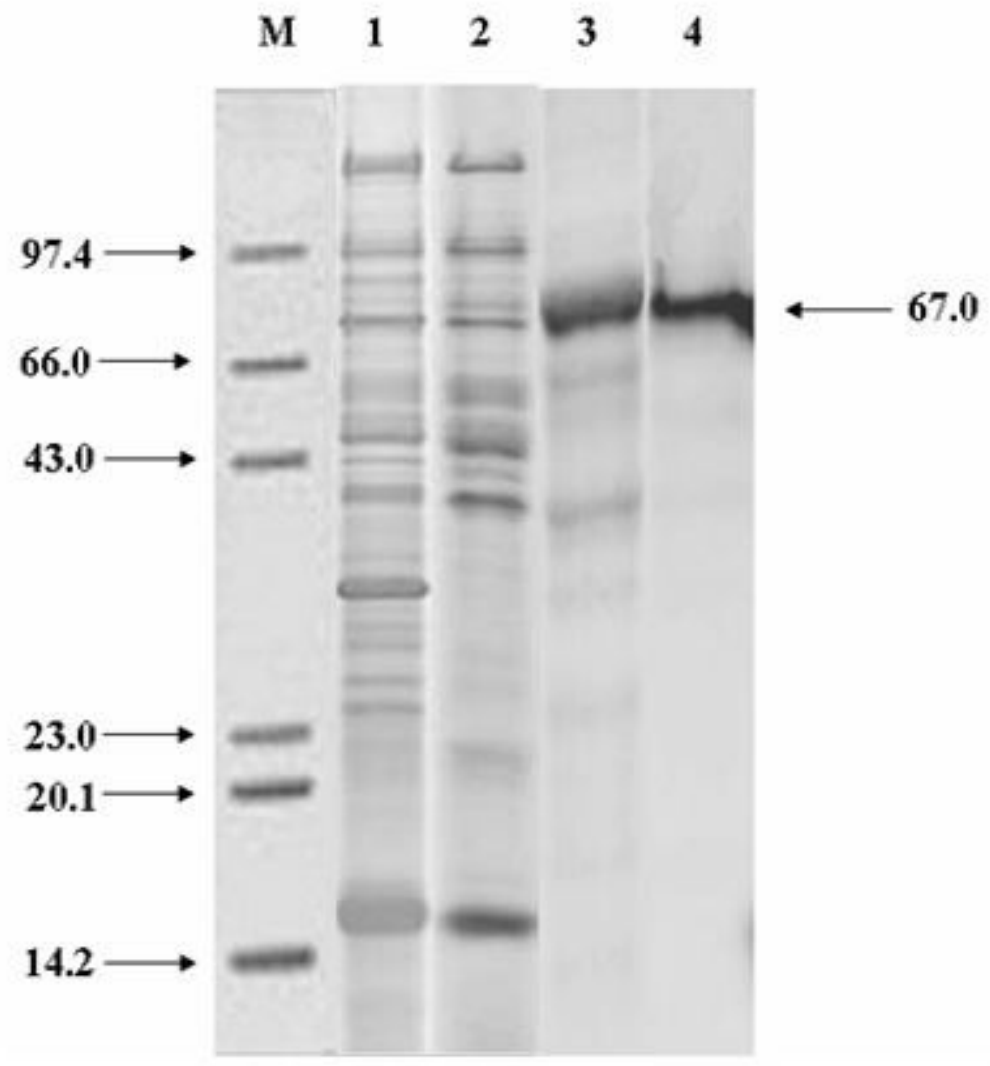

\section{Figure 4}

Photographic representation of the SDS-PAGE of different fractions of amylase of Bacillus subtilis obtained during purification steps. Lane 1: Marker proteins; lane 2: Crude supernatant; lane 3:

Concentrated enzyme after acetone precipitation; lane 4: Purified enzyme obtained after anion-exchange chromatography; lane 5: Purified enzyme obtained after gel-filtration chromatography. Molecular weights were presented in the form of $\mathrm{kDa}$. 


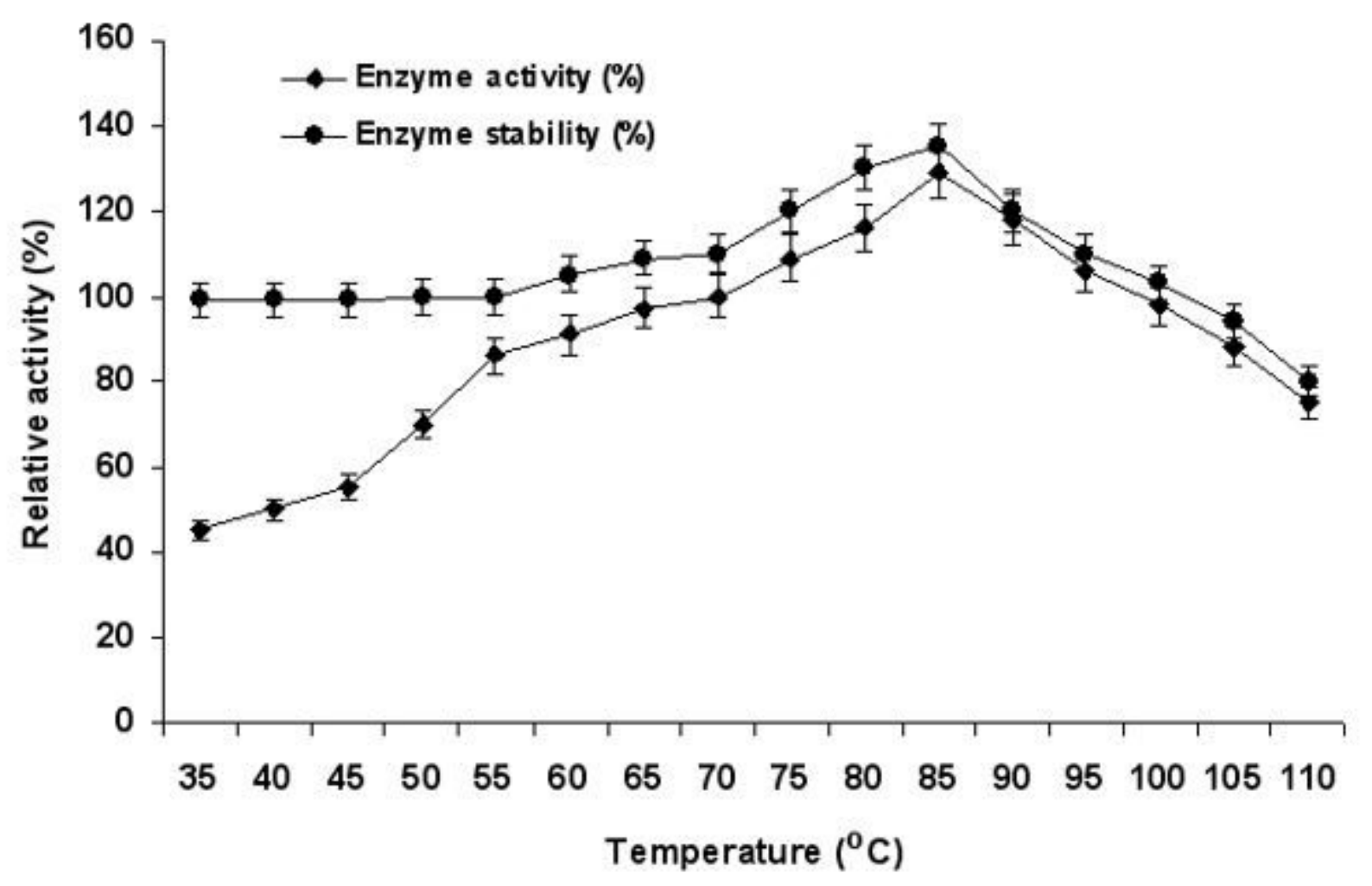

Figure 5

Effect of temperature on enzyme activity and stability. For enzyme activity reaction mixture was incubated at different temperatures $\left(35-110^{\circ} \mathrm{C}\right)$ and for stability enzyme was pre-incubated at respective temperatures for $1 \mathrm{~h}$ and reaction was conducted as standard assay method. 


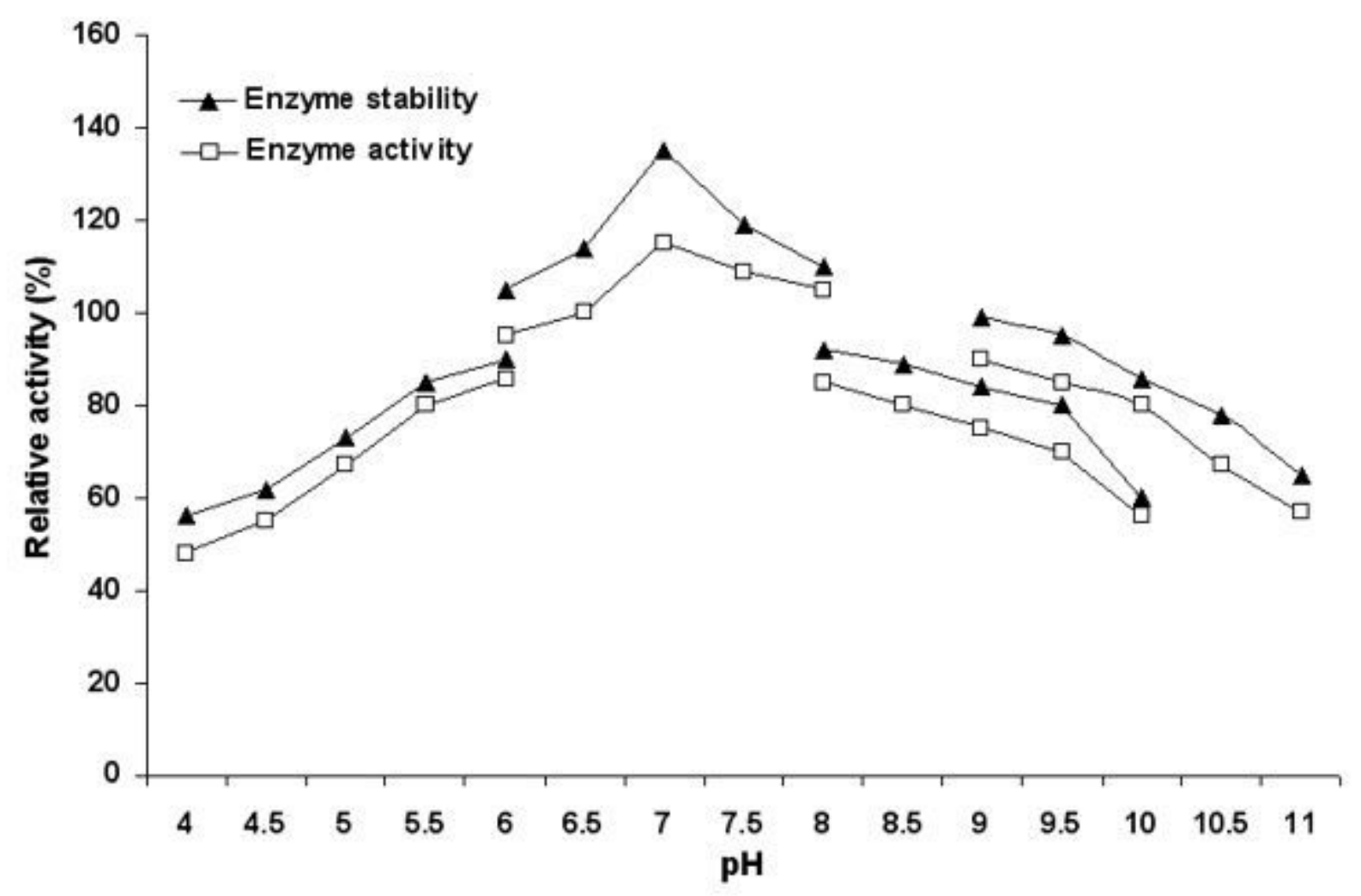

Figure 6

Effect of pH on enzyme activity and stability. For enzyme activity the reaction was assayed at respective $\mathrm{pH}$ and for stability enzyme was pre-incubated with buffers $(100 \mathrm{mM}$, in ratio 1:1) of different $\mathrm{pH}(4-11)$ at $55^{\circ} \mathrm{C}$ for $1 \mathrm{~h}$ and assayed by standard assay method. 


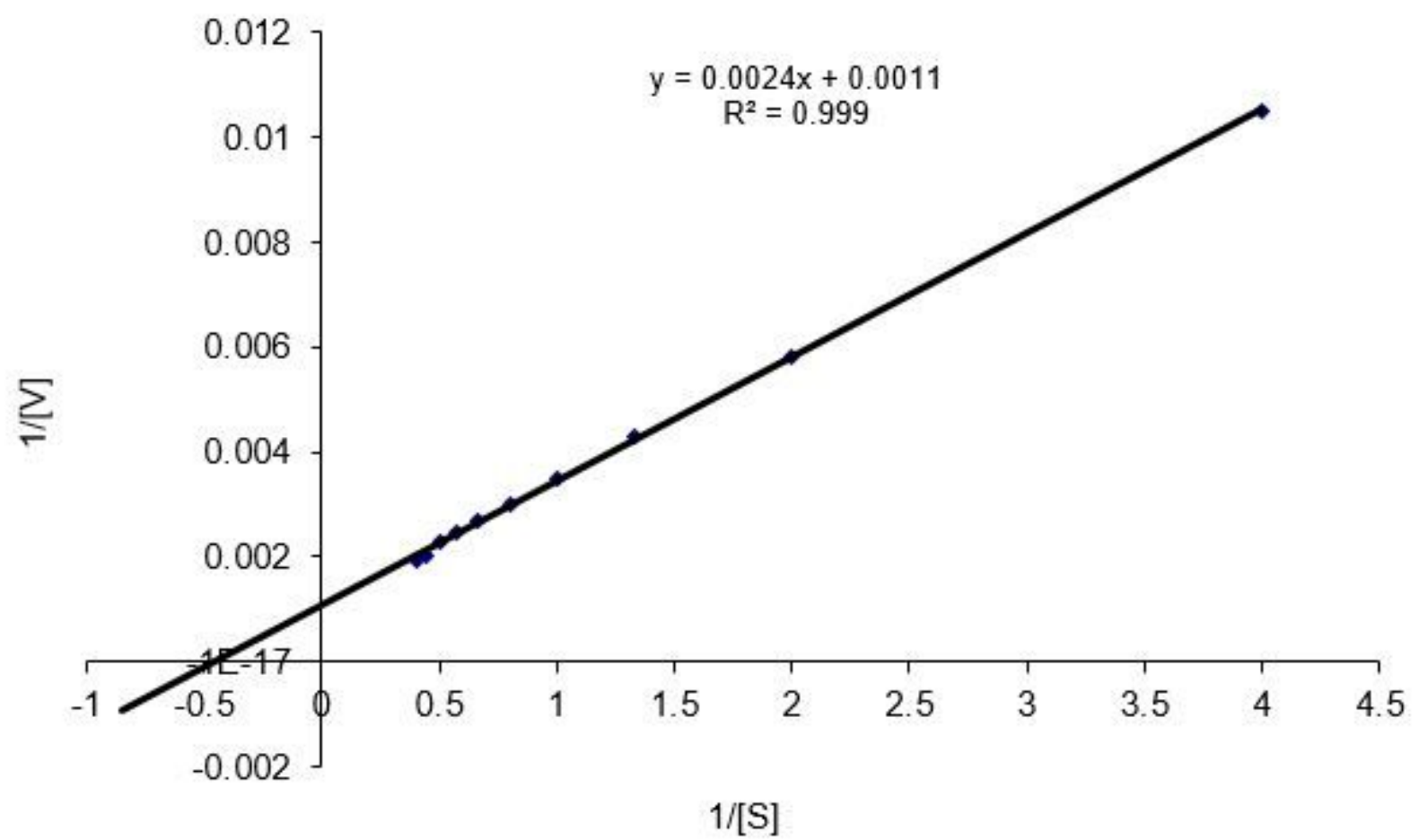

Figure 7

Lineweaver-burk plot of amylase enzyme of Bacillus subtilis.

\section{Supplementary Files}

This is a list of supplementary files associated with this preprint. Click to download.

- Graphicalabstract.docx 